\title{
Rheumatoid arthritis hand lesions assessed with outcome measures in rheumatoid arthritis clinical trials-rheumatoid arthritis magnetic resonance imaging score - proposing an extended rheumatoid arthritis magnetic resonance imaging score
}

\author{
M. del Carmen Larios-Forte' ${ }^{1}$ Mario A. Garza-Elizondo², Cassandra M. Skinner-Taylor², \\ Jorge A. Esquivel-Valerio², David Vega-Morales², Dionicio A. Galarza-Delgado², Diana E. Flore-Alvarado², \\ Rodrigo E. Elizondo-Omaña ${ }^{3}$, and Alejandro Quiroga-Garza ${ }^{3 *}$ \\ ${ }^{1}$ Radiology and Research Division, Hospital Regional Monterrey, Instituto de Seguridad y Servicios Sociales de los Trabajadores del Estado \\ (ISSSTE); ${ }^{2}$ Rheumatology Department, Internal Medicine Division, Hospital Universitario “Dr. José Eleuterio González," Universidad Autónoma de \\ Nuevo Leon; ${ }^{3}$ Human Anatomy Department, School of Medicine, Universidad Autónoma de Nuevo Leon. Monterrey, Nuevo León, Mexico
}

\begin{abstract}
Introduction: The Outcome Measures in Rheumatoid Arthritis Clinical Trials (OMERACT) and Rheumatoid Arthritis Magnetic Resonance Imaging Score (RAMRIS), with the EULAR-OMERACT-2005 MR-Atlas, demonstrate characteristics and lesion degrees (synovitis, erosions, bone marrow edema [BME]) in rheumatoid arthritis (R.A.) clinical diagnosis for follow-up and treatment response. Our study's objective was to use RAMRIS in patients from three R.A. phases to detect lesions according to their tissue characterization (fluid levels in tissue) using different magnetic resonance imaging (MRI) sequences. Methods: Sixty contrast-enhanced MRIs from R.A. patients (clinical suspect arthralgia [CSA] - 38\%, early R.A. [ERA] - 37\%, and established [R.A.] - 25\%) were evaluated according to the American College of Rheumatology (ACR-EULAR)-2010 criteria. R.A. lesions evaluation was performed with RAMRIS/Atlas/scoring; our analysis added the presence of lesions in the thumb and wrist (tenosynovitis, synovitis, erosions, and BME), proposing an "extended RAMRIS." Results: Overall, 83\% (50/60) women, mean $42 \pm 13.5$ (19-70) years-of-age, from 1731 evaluated sites, 964 lesions were identified. Synovitis 46\% (445/964) was most frequently found in the carpal bones $72 \%$ (321/445). Extended RAMRIS demonstrated tenosynovitis and erosions in $1^{\text {st }}$ carpometacarpal, $1^{\text {st }}$ metacarpophalangeal, and hand-wrist tenosynovitis. Gadolinium contrast showed synovial and erosions enhancement indicating active lesions, most predominantly in ERA. Conclusions: Extended RAMRIS score was not statistically different $(p=0.43)$ from RAMRIS-2005. However, it considers all hand-wrist bone joint sites and tendon lesions needed for assessing a more accurate degree of disease development. A proposed extended RAMRIS should be considered.
\end{abstract}

Key words: Rheumatoid arthritis. Magnetic resonance imaging. Outcome measures in rheumatoid arthritis clinical trials-rheumatoid arthritis magnetic resonance imaging score. Extended rheumatoid arthritis magnetic resonance imaging score. 


\section{Introduction}

Outcome measures in rheumatoid arthritis (R.A.) Clinical Trials-R.A. Magnetic resonance imaging score (OMERACT-RAMRIS) group developed R.A. magnetic resonance imaging (MRI) scoring system to follow and assess the R.A. destructive changes response in treated patients, performing the RAMRIS score and the EULAR-OMERACT Atlas-2005, for hand-wrist joint lesions: synovitis, erosions, and bone marrow edema (BME) (or osteitis) ${ }^{1-5}$. However, there are visibly detectable structural lesions by MRI, not described, nor applied in RAMRIS 2005 score such as the $1^{\text {st }}$ carpometacarpal (CMC) and $1^{\text {st }}$ metacarpophalangeal (MCP) joints, and hand-wrist (compartments) tenosynovitis.

Glinatsi et al. (2017) developed, validated, and proposed to add the MRI tenosynovitis score (RAMRIS-TS) in nine hand-wrist tendons compartments and four flexor tendon MCP joint compartments (with scale 0-3 for negative, mild, moderate, or severe tenosynovitis, respectively), as a sensitive and reliable tool to evaluate R.A. patients in clinical trials ${ }^{6,7}$.

R.A. an autoimmune, polyarticular, systemic inflammatory synovial joint, and peritendinous disease with cartilage destruction and bone erosions leads to bone deformation and functional disability, starting in small joints (hands and feet). Its development goes through a preclinical phase (genetic, environmental, and autoimmune) without symptoms, that progress to symptomatic phases: clinically suspect arthralgia (CSA - patients with clinically suspect arthralgia without detectable inflammatory signs), early R.A. (ERA - with clinically detectable inflammation and onset of $<2$ years), and established R.A. (more than 2 years onset symptoms $)^{2,8-11}$.

The OMERACT expert group gathered in Australia in 2002, determining MRI has improved detection of joint damage and recommended it as the best current imaging tool for R.A. assessment. They validated the RAMRIS score for monitoring the patient during treatment $^{1}$, as MRI provides tissue characterization in lesions, offers an advantage by demonstrating joint structural changes from the beginning, even in CSA, with a sensitivity of $66 \%$ to detect synovitis, $94 \%$ for BME (describing grades: 0-3 or mild, moderate, and severe in both), and $98 \%$ for erosions (with grades $1-10 \%$ depending on the number of erosions present) ${ }^{9}$. The aim of RAMRIS is the monitoring and treatment control in all R.A. patients ${ }^{12}$. However, it has also been misused as an R.A. diagnostic and description tool.
Our study's objective was to use RAMRIS in patients from three R.A. phases to detect lesions according to their tissue characterization (fluid levels in tissue) using different MRI sequences.

\section{Methods}

This is an exploratory, observational, descriptive, and non-blinded cohort with a setting in a northern Mexican population of Monterrey, Nuevo León, Mexico obtained from the Rheumatology Department, "Dr. José Eleuterio González," University Hospital, UANL. The study was previously approved by the Ethics and Research Committees, applying the concerning authorized body study (informed consent), with registration number RE-17-00010.

All patients were assessed according to the 2010 American College of R.A. classification criteria ${ }^{9,13}$. A total of 60 patients (older than 18 years, both sexes) were enrolled and classified by certificated rheumatologists into three different R.A. disease phases: CSA (of which all had a first-degree relative with R.A.), ERA (patients with $<2$ years of onset of symptoms), and established R.A. (patients with more than 2 years of onset of symptoms). All patients underwent a hand-wrist MRI (1.5 Teslas, Signa Twin HDx of General Electric-GE, using a hand-wrist joint antenna). T1 simple, post-intravenous Gadolinium T1 and Short tau inversion recovery (STIR) sequences (with 17-19 coronal and axial slices, thickness $=2 \mathrm{~mm}$, interslice gap $=0 \mathrm{~mm}$, and matrix $=512 / 512)($ Table 1$)$. Anti-inflammatory drugs were suspended $24 \mathrm{~h}$ prior to the study. Studies were evaluated with the OMERACT-RAMRIS system and the European R.A. League - EULAR-OMERACT 2005 Atlas $^{14}$. In the early stages of the study, thorough MRI assessment revealed lesions such as tenosynovitis, synovial effusion, and evaluation of the $1^{\text {st }}$ CMC and MCP. These were recorded as added parameters to the RAMRIS classification and are proposed as an extended RAMRIS.

Our study uses the RAMRIS system to analyze hand/ wrist complex in patients from three different R.A. phases and determine lesions according to the tissue characterization in different MRI sequences. The MRI post-gadolinium intravenous contrast enhancement in joint synovitis or synovial erosions was described as active disease lesions (due to the disease's focal autoimmune inflammatory neoangiogenesis).

Demographic parameters were recorded (age, sex, and dominant hand), as well as clinical characteristics assessed with the Visual Analogue Scale (EVA - 0-10), 
Table 1. Hand and wrist MRI scanning protocol

\begin{tabular}{|c|c|c|c|c|c|c|c|c|c|}
\hline Sequences & $\begin{array}{l}\text { TR/TE } \\
\text { (ms) }\end{array}$ & $\begin{array}{c}\text { Slice } \\
\text { thickness (mm) }\end{array}$ & $\begin{array}{l}\text { Interslice } \\
\text { gap (mm) }\end{array}$ & \#Slices & Matrix & $\begin{array}{l}\text { Time Scan } \\
\text { (Min) }\end{array}$ & Nex. & $\begin{array}{l}\text { Flip } \\
\text { angle }\end{array}$ & $\begin{array}{c}\text { Field of } \\
\text { view (FOV) }\end{array}$ \\
\hline Locator (3 levels) & $6 / 2$ & 3 & 5 & 27 & $256 \times 256$ & 5 & 1 & 30 & 300 \\
\hline 1. Axial T1 FSE MCP & $716 / 12$ & 2 & 2 & 19 & $512 \times 512$ & 5 & 2 & 90 & 120 \\
\hline $\begin{array}{l}\text { 2. Coronal T1 FSE } \\
\text { Wrist and MCP }\end{array}$ & $550 / 11$ & 2 & 0 & 17 & $512 \times 512$ & 4 & 2 & 90 & 170 \\
\hline $\begin{array}{l}\text { 3. Coronal STIR Wrist } \\
\text { and MCP }\end{array}$ & $5116 / 29$ & 2 & 0 & 17 & $512 \times 512$ & 4 & 2 & 90 & 170 \\
\hline 4. Axial T1 FSE Wrist & $733 / 11$ & 2 & 0 & 19 & $512 \times 512$ & 5 & 2 & 90 & 120 \\
\hline $\begin{array}{l}\text { 5. Coronal T1 FSE with } \\
\text { Gad. IV Wrist and } \\
\text { MCP }\end{array}$ & $550 / 11$ & 2 & 0 & 17 & $512 \times 512$ & 4 & 2 & 90 & 170 \\
\hline $\begin{array}{l}\text { 6. Axial T1 FSE with } \\
\text { Gad. IV MCP }\end{array}$ & $733 / 11$ & 2 & 0 & 19 & $512 \times 512$ & 5 & 2 & 90 & 120 \\
\hline $\begin{array}{l}\text { 7. Axial T1 FSE with } \\
\text { Gad. IV Wrist }\end{array}$ & $750 / 11$ & 2 & 0 & 19 & $512 \times 512$ & 5 & 2 & 90 & 120 \\
\hline
\end{tabular}

MRI SIGNA Twin HDx 1.5 Tesla, GE, in dominant hand: pulse-sequences parameters for visualization from first-through-to-fifth metacarpal-phalangeal (MCP) joints and wrist of the most painful hand. T.R.: time recovery (ms: millisecond); T.E.: time echo (ms); mm: millimeter; Min: minutes; FSE: fast spin echo; STIR: short tau inversion recovery; Gad IV: intravenous gadolinium, GAP space.

and counting the number of painful and swollen joints amongst 28 joints, that determinate the Disease Activity Score (DAS 28 - normal score lower than 3.2). Laboratory serum tests for Anticitrullinated peptide antibodies (Anti CCP), rheumatoid factor, $\mathrm{C}$ reactive protein, and erythrocyte sedimentation rate were also included (Table 2).

MRI images were assessed by an experienced radiologist, familiarized in RAMRIS scoring, evaluating synovitis, bone erosion, BME (or osteitis), and tenosynovitis. The included sites were the first-through-fifth MCP joints, carpal bones, distal radius, distal ulna, radiocarpal, intercarpal, $\mathrm{CMC}$, and distal radioulnar joints(Fig. 1).

The MRI identified lesions were as follows: Bone Erosion: sharply marginated bone lesion with juxta-articular localization, and typical characteristics of decrease signal visible on two planes in T1 and STIR sequences, with a cortical break detection on at least one plane. The score was based on a scale of 0-10 based on the proportion of eroded bone to the assessed bone volume as judged from all available images ( 0 , no erosion; $1,1 \%$ to $10 \%$ of bone eroded; 2 , $11 \%$ to $20 \%$ of bone eroded, etc.). Synovitis: lesion in the synovial compartment with an increased signal on STIR images and a thickness greater than the width of the normal synovial membrane evaluating four wrist regions (the distal radioulnar joint, the radiocarpal joint, the intercarpal joint, and the CMC joint in each finger); scored from 0 to 3 grades ( 0 none, 1 mild, 2 moderate, 3 severe). BME or Osteitis: a lesion in the trabecular bone with ill-defined margins and increased water content signal in the STIR sequence. The scoring scale ranged from 0 to 3 and was used to rate the proportion of bone with edema as follows ( 0 , no edema; $1,1 \%$ to $33 \%$ of edematous bone; $2,34 \%$ to $66 \%$ of edematous bone; $3,67 \%$ to $100 \%$ of edematous bone) $)^{15,16}$ (Fig. 2). Tenosynovitis: visualized fluid in the tendon sheath contour, sheath thickening, and an increased signal on T2 fat-suppressed on STIR sequences (scored 0-3: none to severe). Separate anatomical areas of the wrist were assessed: the six extensor compartments and four regions on the volar side, namely, the flexor carpi ulnaris, the ulnar bursa including the flexor digitorum profundus and superficialis (FDP/FDS), the flexor pollicis longus in the radial bursa, and the flexor carpi radialis (Fig. 3$)^{6}$.

\section{Statistical analysis}

All statistical analyses were performed with the IBM SPSS version 22.0 (IBM Co., Armonk, NY, USA). The continuous variables were expressed as mean, and the categorical variables were presented as frequencies and proportions. 
Table 2. Demographic parameters, clinical characteristics, and laboratory tests. Study group in three RA stages

\begin{tabular}{|c|c|c|c|c|c|}
\hline & $\begin{array}{c}\text { CSA } \\
(n=23) \\
38 \%\end{array}$ & $\begin{array}{c}\text { ERA } \\
(n=22) \\
37 \%\end{array}$ & $\begin{array}{c}\text { RA } \\
(n=15) \\
25 \%\end{array}$ & CI $95 \%$ & $\mathbf{p}$ \\
\hline \multicolumn{6}{|c|}{ Demographic parameters } \\
\hline $\begin{array}{l}\text { Age } \\
\text { median y range } \\
>40 \text { years } \\
<40 \text { years }\end{array}$ & $\begin{array}{c}35(26-61) \\
4(17) \\
19(83)\end{array}$ & $\begin{array}{c}50(29-70) \\
16(73) \\
6(27)\end{array}$ & $\begin{array}{c}52(19-67) \\
11(73) \\
4(27)\end{array}$ & & 0.001 \\
\hline $\begin{array}{l}\text { Gender } \\
\text { Female }\end{array}$ & $18(78)$ & $18(82)$ & $14(93)$ & & \\
\hline $\begin{array}{l}\text { Dominant hand } \\
\text { Right }\end{array}$ & $22(96)$ & 20 (91) & $13(87)$ & & \\
\hline $\begin{array}{l}\text { Clinical characteristics } \\
\text { Onset Year Symptom (\%): }\end{array}$ & $2 \mathrm{yr}(83)$ & $2 y r(64)$ & $7 y r(67)$ & & \\
\hline $\begin{array}{l}\text { Clinical year diagnosis } \\
2004-2008(\%) \\
2010-2015 \\
2016-2017\end{array}$ & $\begin{array}{c}0 \\
3(13) \\
20(87)\end{array}$ & $\begin{array}{c}0 \\
5(23) \\
17(77)\end{array}$ & $\begin{array}{c}4(27) \\
6(40) \\
5(33.3)\end{array}$ & & \\
\hline $\begin{array}{l}\text { EVA }(0-100) \\
\text { Mean }\end{array}$ & $\begin{array}{c}n=18 \\
1\end{array}$ & $\begin{array}{c}n=22 \\
3\end{array}$ & $\begin{array}{c}n=15 \\
5\end{array}$ & $21-38$ & 0.0 \\
\hline $\begin{array}{l}\text { \# Painful joints } \\
\text { Mean }\end{array}$ & $\begin{array}{c}n=19 \\
2\end{array}$ & $\begin{array}{c}n=20 \\
8\end{array}$ & $\begin{array}{c}n=14 \\
11\end{array}$ & $4.6-8$ & 0.0 \\
\hline $\begin{array}{l}\text { \# Swollen joints } \\
\text { Mean }\end{array}$ & $\begin{array}{c}n=19 \\
1\end{array}$ & $\begin{array}{c}n=19 \\
7\end{array}$ & $\begin{array}{c}n=14 \\
8\end{array}$ & $3-7$ & 0.0 \\
\hline $\begin{array}{l}\text { DAS } 28>3.2 \\
\text { Mean }\end{array}$ & $\begin{array}{c}n=17 \\
2\end{array}$ & $\begin{array}{c}n=20 \\
4\end{array}$ & $\begin{array}{c}n=11 \\
5.6\end{array}$ & $3-5$ & 0.0 \\
\hline \multicolumn{6}{|c|}{ Laboratory serum tests } \\
\hline $\begin{array}{l}\text { Laboratories } \\
\text { Anti CCP (8-17U) } \\
\text { Mean } \\
\text { RF (40-60U/mL) } \\
\text { Mean } \\
\quad \text { Range } \\
\text { CRP }(<1.0 \mathrm{mg} / \mathrm{dl}) \\
\text { Mean } \\
\text { ESR }(15-20 \mathrm{~mm} / \mathrm{h}) \\
\text { Mean }\end{array}$ & $\begin{array}{c}n=22 \\
24 \\
n=20 \\
79 \\
1.0-200 \\
n=20 \\
0.7 \\
n=20 \\
14\end{array}$ & $\begin{array}{c}\mathrm{n}=21 \\
257 \\
\mathrm{n}=22 \\
99 \\
1.0-380 \\
\mathrm{n}=21 \\
5 \\
\mathrm{n}=21 \\
25\end{array}$ & $\begin{array}{c}\mathrm{n}=2 \\
51 \\
\mathrm{n}=8 \\
20 \\
1.0-71 \\
\mathrm{n}=7 \\
1 \\
\mathrm{n}=11 \\
37\end{array}$ & $\begin{array}{l}6-274 \\
55-101\end{array}$ & $\begin{array}{l}0.3 \\
0.0\end{array}$ \\
\hline
\end{tabular}

Anti CCP: anti-cyclic citrullinated peptide; CRP: C - reactive protein; CSA: clinical suspicious arthralgia; ERA: early rheumatoid arthritis; ESR: erythrocyte sedimentation rate; $\mathrm{n}$ : sample size; RA established: rheumatoid arthritis; yr: year rheumatoid factor.

\section{Patient and public involvement}

Patient involvement was obtained in the Rheumatology Outpatient Clinic by the participating rheumatologist. Patients were informed orally (in Spanish) of the study and invited to participate. Those who accepted were then explained the study's details, their participation, and the corresponding documents (in Spanish) to obtain signed consent. No information was withheld, and researchers were available throughout, giving patients time to ask any questions or withdraw their participation. Patients were then given instructions and scheduled for dominant hand MRI, free of charge. Patients were not paid to participate. Their findings were shared and explained with each patient in a follow-up appointment. This study's results will not be shared individually with each patient but will be at their disposal upon request.

\section{Results}

A total of 60 patients were included in the study, with a mean age of $42 \pm 13.5$ years (19-70), 83\% (50/60) women and $17 \%$ (10/60) men, classified into three R.A. 
Hospital Umiversitamio Dedosé Eleuterio Gonzalez UAWL Néxico

\section{EXTENDED RAMRIS}
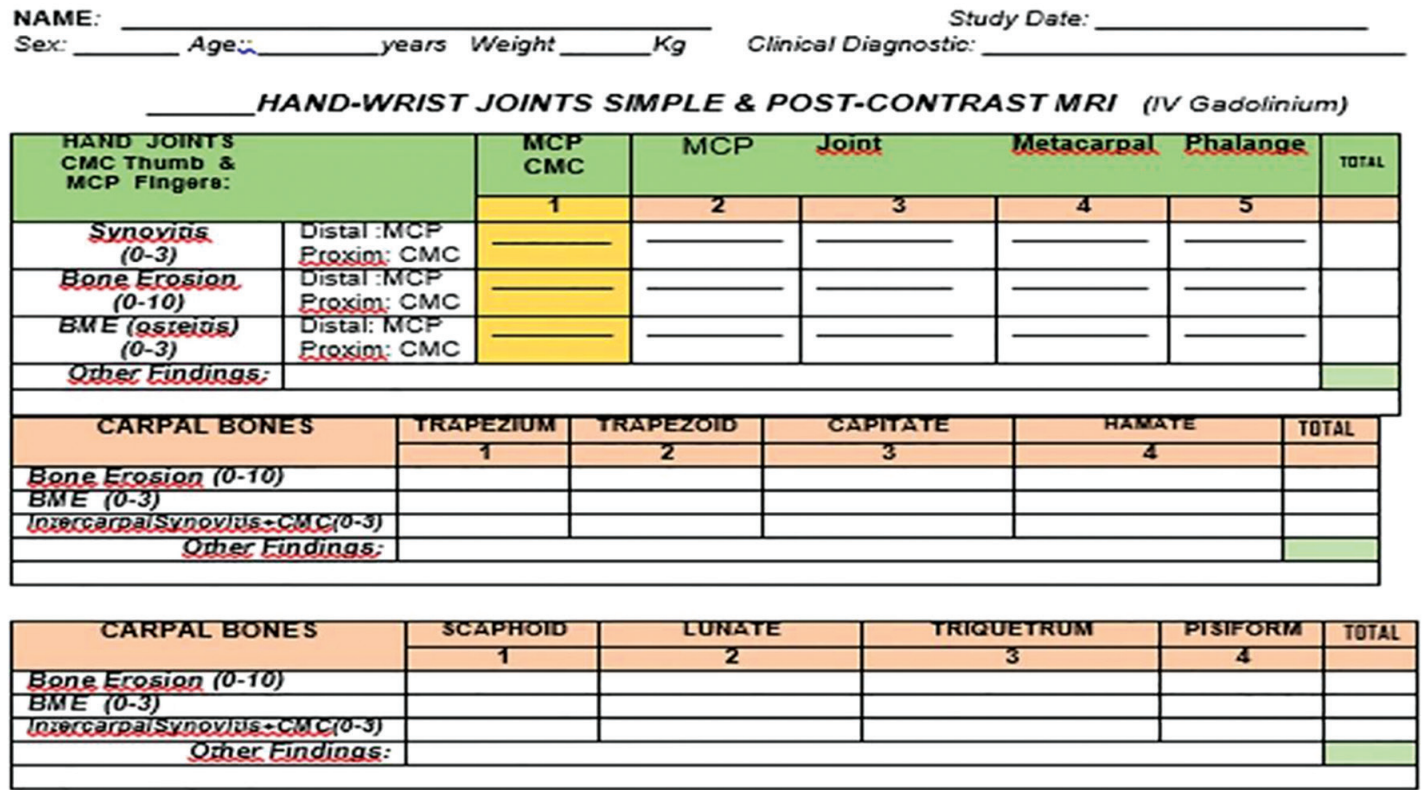

\begin{tabular}{|c|c|c|c|c|c|}
\hline $\begin{array}{l}\text { WRIST } \\
\text { JOINTS }\end{array}$ & $\begin{array}{c}\text { Diszal Radio-Uूar } \\
\text { doinz }\end{array}$ & Radio-Cacaal doinz & Llno-Carnal J & $\begin{array}{l}\text { Fipcesaculage } \\
\text { Iriangle }\end{array}$ & Total \\
\hline \multicolumn{6}{|l|}{ Sinovias $(0-3)$} \\
\hline & Discal Radio & Diszal प्uma & TnIAl 23 Sites & & \\
\hline Bone Ecosion $(0-10)$ & & & sinoe $=$ & & \\
\hline BME $(0-3)$ & & & Eros= & & \\
\hline Tenesymevins $(0-3)$ & & & BRाE= & & \\
\hline \multirow[t]{2}{*}{ ower Eladiogs: } & & & Total= & & \\
\hline & & & इ Tarles- & & \\
\hline
\end{tabular}

Diagnostic Impression:ec

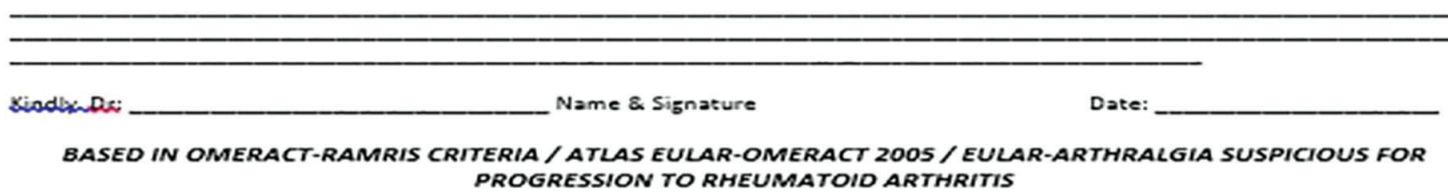

Figure 1. The included magnetic resonance imaging sites were: first-through-to-fifth metacarpophalangeal joint carpal bones, intercarpal joints, distal radioulnar joint, distal radius, distal ulna, radiocarpal, and ulnar-carpal joints; the tenosynovitis and wrist compartment.

stages: CSA (n 23, 38\%), ERA (n 22, 37\%), and A.R. (n 15, 25\%) according to ACR/EULAR 2010 criteria. The dominant hand-wrist MRI was performed in all patients, evaluating 1731 hand-wrist joint bone sites, determining 964 sites with lesions (synovitis, erosions, BME, and tenosynovitis) (Figs. 2-4).

The three groups were assessed by RAMRIS 2005 and the Extended RAMRIS (which includes the $1^{\text {st }} \mathrm{CMC}, 1^{\text {st }} \mathrm{MCF}$, and hand-wrist tenosynovitis). Synovitis was the most frequent type of lesion (46\%, $445 / 964)$, and the carpal bones were the most frequently affected site $(72 \%, 321 / 445)$. Triquetral bone synovitis was the most persistent lesion $(40 \%, 54 / 135)$ in all R.A. stages. ERA phase demonstrated predominance for carpal tenosynovitis (due to synovitis in extensor-dorsal and volar-flexor retinaculum) (Table 3).

Gadolinium contrast showed enhancement in synovial and erosions lesions. This indicates "active lesions" at the time the MRI study was being performed. The ERA patients were the most predominant with active erosions ( $n=52 / 117$ [44\%]) compared CSA and established R.A.

\section{Discussion}

This study evaluated patients with R.A. hand lesions assessed by OMERACT-RAMRIS 2005 Score and a 
Table 3. Most frequent carpal and distal radioulnar joint tenosynovitis in three RA stages

\begin{tabular}{|c|c|c|c|c|}
\hline $\begin{array}{l}\text { Tendons, } \\
\text { ligaments, and } \\
\text { retinaculum } \\
\text { more affected }\end{array}$ & $\begin{array}{c}\text { CSA + ERA } \\
+ \text { RA (Total } \\
n=60) n(\%)\end{array}$ & $\begin{array}{c}\text { CSA } \\
(n=23) \\
n(\%)\end{array}$ & $\begin{array}{c}\text { ERA } \\
(n=22) \\
n(\%)\end{array}$ & $\begin{array}{c}\text { RA } \\
(n=15) \\
n(\%)\end{array}$ \\
\hline $\begin{array}{l}\text { Extensor } \\
\text { Retinaculum } \\
\text { (Dorsal) } \\
\text { Wrist } \\
\text { Tenosynovitis } \\
\text { (ERWT) and } \\
\text { Angular Dorsal } \\
\text { Wrist } \\
\text { Ligament }\end{array}$ & $26(43)$ & $3(13)$ & $12(54)$ & $11(73)$ \\
\hline $\begin{array}{l}\text { Flexor } \\
\text { Retináculum } \\
\text { (Volar) } \\
\text { Wrist } \\
\text { Tenosynovitis } \\
\text { (FRWT) } \\
\text { and Angular } \\
\text { Volar Wrist } \\
\text { Ligament }\end{array}$ & $26(43)$ & $5(22)$ & $12(54)$ & $9(60)$ \\
\hline $\begin{array}{l}\text { Flexor } \\
\text { Digitorum } \\
\text { Profundus } \\
\text { Tenosynovitis } \\
\text { (FDPT) }\end{array}$ & $16(27)$ & $5(22)$ & $5(23)$ & $6(40)$ \\
\hline $\begin{array}{l}\text { Flexor Pollicis } \\
\text { longus } \\
\text { Tenosynovitis } \\
\text { (FPLT) }\end{array}$ & $9(15)$ & $1(4)$ & 4 (18) & $4(27)$ \\
\hline $\begin{array}{l}\text { VI Extensor } \\
\text { (Dorsal) Carpi } \\
\text { Ulnaris } \\
\text { Tenosynovitis } \\
\text { Compartment } \\
\text { (ECUT) }\end{array}$ & 8 (13) & $1(4)$ & $5(23)$ & $2(13)$ \\
\hline $\begin{array}{l}\text { Total } \\
\text { Intra-group }\end{array}$ & $85(100)$ & $15(18)$ & $38(45)$ & 32 (37) \\
\hline
\end{tabular}

CSA: clinical suspicious arthralgia; ERA: early rheumatoid arthritis; RA: established rheumatoid arthritis; n: sample.

proposed extended RAMRIS in three different stages: CSA, ERA, and established R.A. (Table 4).

There are several prior studies that evaluate R.A. patients with MRI using the OMERACT-RAMRIS scoring ${ }^{17-23}$. Kyung-Ann et al. ${ }^{17}$ used RAMRIS to detect synovitis, bone erosions, osteitis (or BME), and tenosynovitis in the wrist and MCF joints in 43 patients concluding that erosions and BME are more frequent in the capitate, lunate, triquetral, and hamate bones. Glinatsi et al. ${ }^{7}$ validated the inclusion of tenosynovitis into RAMRIS as a reliable tool. Van Steenbergen et al..$^{18}$ assessed 150 CSA patients, concluding it precedes clinical arthritis in a few

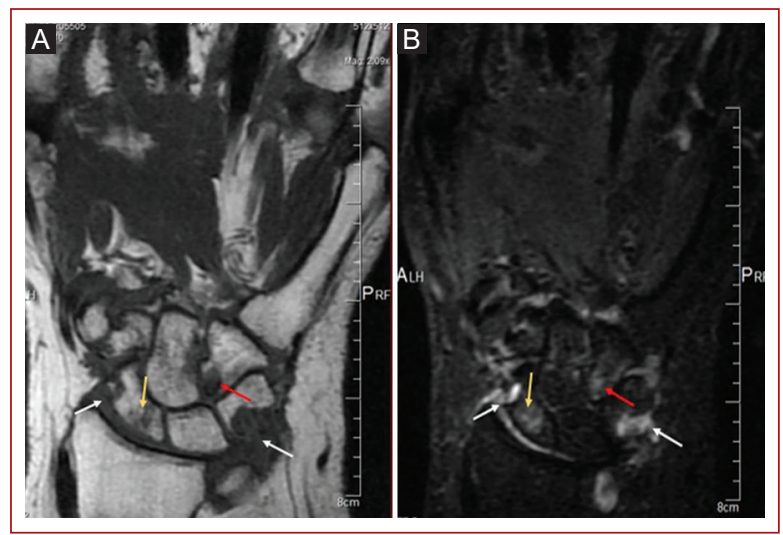

Figure 2. A: Magnetic resonance imaging T1 coronal. B: short tau inversion recovery coronal. Images with carpal lesions: ERA female (57 years old); triquetral and distal radioulnar joint synovitis lesions in white arrow (score $=1)$; hamate and bone erosions lesions in red arrow (score $=2 \%$ ); and scaphoid bone marrow edema (osteítis) lesions in yellow arrow (score $=1$ ).

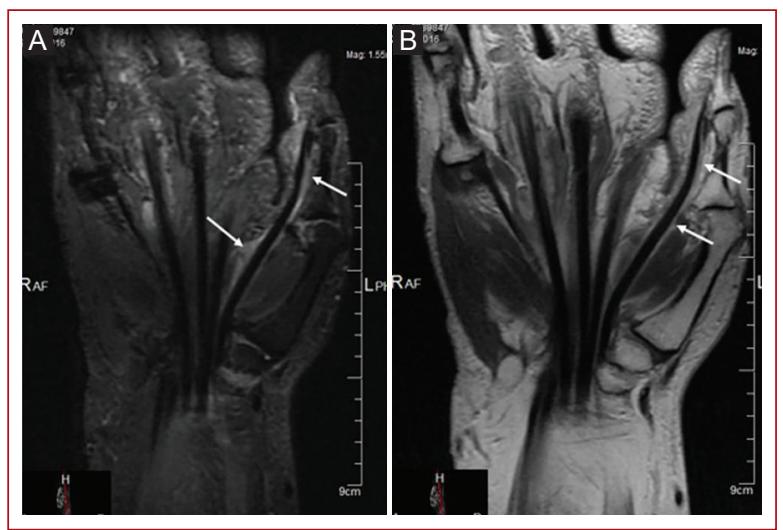

Figure 3. A: Magnetic resonance imaging short tau inversion recovery coronal. B: post-gadolinium T1 coronal. Images with tenosynovitis: CSA Female (29 years old); with flexor pollicis longus tendon sheath with tenosynovitis lesion in white arrow (score $=2$ ).

months, and inflammation is independent of other factors such as anti-CCP. Erol et al. ${ }^{19}$ assessed the established R.A. by MRI in 33 patients, concluding that synovitis and osteitis are significantly elevated in patients with longer disease duration. Woodworth et al. ${ }^{15}$ assessed the validity of RAMRI with a systemic literature review of 634 MRI titles/abstracts, where 26 articles utilized RAMRIS, concluding that RAMRIS is useful and valid to evaluate synovitis, BME, and erosions in R.A. Kosta Paraskevi et al. ${ }^{20}$, evaluated very ERA, ERA, and R.A. in 57 patients, concluding that $\mathrm{BME}$, erosions, and synovitis are findings from very ERA Spina et al. ${ }^{21}$, evaluated the ERA in 
Table 4. Assessed RAMRIS 2005 and extended RAMRIS stratified by R.A. phase (means)

\begin{tabular}{|c|c|c|c|c|c|c|c|c|c|}
\hline & \multicolumn{4}{|c|}{ RAMRIS 2005} & \multicolumn{5}{|c|}{ Extended RAMRIS } \\
\hline & Synovitis & Erosion & Osteitis & Total & Synovitis & Erosion & Osteitis & Tenosynovitis & Total \\
\hline $\begin{array}{c}\text { MCP } \\
\text { CSA } \\
\text { ERA } \\
\text { RA }\end{array}$ & $\begin{array}{l}2 \\
6 \\
7\end{array}$ & $\begin{array}{l}2 \\
3 \\
5\end{array}$ & $\begin{array}{c}0.4 \\
0 \\
3\end{array}$ & $\begin{array}{c}4.4 \\
9 \\
15\end{array}$ & $\begin{array}{c}4 \\
10 \\
12\end{array}$ & $\begin{array}{l}2 \\
4 \\
6\end{array}$ & $\begin{array}{c}0.4 \\
0 \\
4\end{array}$ & $\begin{array}{l}1 \\
2 \\
3\end{array}$ & $\begin{array}{l}7.4 \\
16 \\
25\end{array}$ \\
\hline $\begin{array}{c}\text { Carp } \\
\text { CSA } \\
\text { ERA } \\
\text { RA }\end{array}$ & $\begin{array}{l}4 \\
8 \\
5\end{array}$ & $\begin{array}{c}7 \\
10 \\
11\end{array}$ & $\begin{array}{l}1 \\
3 \\
4\end{array}$ & $\begin{array}{l}12 \\
21 \\
20\end{array}$ & $\begin{array}{c}5 \\
14 \\
9\end{array}$ & $\begin{array}{c}8 \\
12 \\
13\end{array}$ & $\begin{array}{l}3 \\
5 \\
9\end{array}$ & $\begin{array}{l}1 \\
3 \\
4\end{array}$ & $\begin{array}{l}17 \\
34 \\
35\end{array}$ \\
\hline $\begin{array}{l}\text { RUJ } \\
\text { CSA } \\
\text { ERA } \\
\text { RA }\end{array}$ & $\begin{array}{l}2 \\
4 \\
4\end{array}$ & $\begin{array}{c}0.4 \\
0.4 \\
1\end{array}$ & $\begin{array}{l}0 \\
1 \\
1\end{array}$ & $\begin{array}{c}2.4 \\
5.4 \\
6\end{array}$ & $\begin{array}{l}2 \\
4 \\
5\end{array}$ & $\begin{array}{c}0.4 \\
1 \\
1\end{array}$ & $\begin{array}{l}0 \\
1 \\
1\end{array}$ & $\begin{array}{l}0 \\
0 \\
1\end{array}$ & $\begin{array}{c}2.4 \\
6 \\
8\end{array}$ \\
\hline Totals & 42 & 40 & 13 & & 65 & 47 & 15 & 15 & \\
\hline Mean & \multicolumn{4}{|c|}{32} & \multicolumn{5}{|c|}{36} \\
\hline
\end{tabular}

Extended RAMRIS Score includes first carpal-metacarpal joint, first metacarpal-phalange, and wrist tenosynovitis. Carp: carpal; RUJ: radioulnar joint; CSA: clinical suspicious arthralgia; ERA: early rheumatoid arthritis; MCP: metacarpophalangeal; R.A. established rheumatoid arthritis; Total RAMRIS mean $p=0.43$ (not significant).

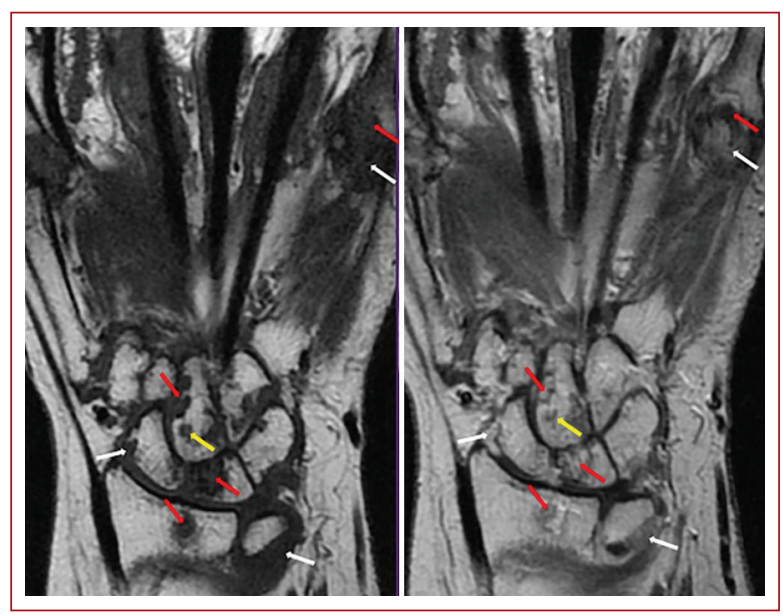

Figure 4. Magnetic resonance imaging T1 simple coronal and post-gadolinium T1 coronal images of hand-wrist. R.A. female ( 65 years old); Gadolinium contrast demonstrates global enhancement in synovial and erosions lesions. This indicates the "active lesions." White arrows show synovitis (score $=3$ ), red arrows show erosions (score $=3$ ), and yellow arrows show BME or osteitis (score $=2$ ).

10 patients concluding that the MRI should be considered in patients with ERA for its prognosis. Finally, Lisbona et al. ${ }^{16}$, in a methodological review, measured R.A. 's structural lesion progression, concluding that MRI is more sensitive in bone lesion detection and allows real assessment of all patients in apparent remission.

All these hand-wrist RAMRIS studies show the diversity and different scoring reports (in percentages, means, summed means, or ranges); also, different MRI techniques parameters (slice thickness, interslice gap, sectional number, matrix, sequences, etc.), without gadolinium contrast application in some studies, and most without a description (score) of the most frequently damaged bone or hand-wrist joint. This dispersion in data report from medical literature may be related to the constant changing (per update) in the performing of M.R. images technique (software's), a higher resolution (512x512 matrix), and thinner slice thickness with null interslice gap $(2 / 0 \mathrm{~mm})$ that allow us to improve MRI detection of lesions, and their R.A. characteristic abnormalities. The difficulty in performing standardized lesion detection in MRI using the OMERACT-RAMRIS ATLAS (2005) must also be taken into consideration.

It is noteworthy to mention that the complete handwrist RAMRIS image assessment is meticulous and consumes a high amount of time per patient, even when evaluated by an expert (>1 h), making it inefficient in some cases. More studies are needed to establish the minimum hand-wrist joints and bones required to determine the effectiveness of MRI in detecting R.A. lesions and prospective studies to determine if MRI findings improve with early treatment.

Although the current study design was not aimed to evaluate treatment response for patients who underwent $\mathrm{MRI}$, it demonstrated in three different R.A. phases with the RAMRIS score performed a common persistent lesion: synovitis and most frequently in the triquetrum. 
We propose using the "Extended" RAMRIS to include tenosynovitis localization, frequency, and intensity. We described details of carpal bone lesions in three different R.A. patient groups, which could well represent the differences between disease time stages, demonstrated by MRI. Although the difference between RAMRIS 2005 versus Extended RAMRIS was not significant, there is a clear difference when adding the $1^{\text {st }} \mathrm{CMC}, \mathrm{MCP}$, and hand-wrist compartments tenosynovitis, increasing the RAMRIS means. Unpublished results presented in the 2018 American College of Rheumatology meeting by Ying-Qian et al. ${ }^{22}$ have also identified tenosynovitis in structures not included in RAMRIS in ERA patients, detecting this deficit. Adding to the RAMRIS score could result in a significant difference in future studies, primarily in patients with ERA, detecting more lesion sites ${ }^{22-24}$.

Our study's limitations are that it does not include treatment response, nor does it include a control group to compare frequency, size, localization, and score of lesions. Images were also assessed by only one radiologist due to the high time consumption and lack of an inter-observer coefficient.

\section{Conclusions}

Evaluating R.A. patients with RAMRIS 2005 score is clinically insufficient to identify enough hand-wrist bones, joints, and tendon lesions to determine the real degree of disease development. Although the proposed Extended RAMRIS did not have a significant difference $(p=0.43$ ), it provides a thorough assessment of lesions, which can be used as a tool to evaluate the follow-up of patient treatment, especially in very early phases where active lesions were most predominant.

\section{Acknowledgments}

Maria del Carmen Larios-Forte would like to thank and acknowledge the support and hard work provided by her daughter, Maria del Carmen Canseco-Larios, M.D., throughout this study.

\section{Conflicts of interest}

The authors declare that they have no conflicts of interest.

\section{Funding}

The project received funding for $\$ 300,000$ MXP from: Dirección General de Planeación y Proyectos
Estratégicos en el Programa para el Desarrollo Profesional Docente para el Tipo (PRODEP), de la Universidad Autónoma de Nuevo León. Cuerpos Académicos (CA) 136

\section{Ethical disclosures}

Protection of people and animals. The authors declare that the procedures followed were in accordance with the ethical standards of the responsible human experimentation committee and in accordance with the World Medical Association and the Declaration of Helsinki.

Confidentiality of the data. The authors declare that they have followed the protocols of their work center on patient data publication

Right to privacy and informed consent. The authors have obtained the patients' informed consent and/ or subjects referred to in the article. This document is in possession of the corresponding author.

\section{References}

1. Østergaard M, Peterfy C, Conaghan P, McQueen F, Bird P, Ejbjerg B, et al. OMERACT rheumatoid arthritis magnetic resonance imaging studies. Core set of MRI adquisition, joint pathology definition and the OMERACT RAMRIS scoring system. J Rheumatol. 2009;30:1385-6.

2. Gerlag DM, Raza K, van Baarsen LG, Brouwer E, Buckley CD, Burmester GR, et al. EULAR recommendations for terminology and research in individuals at risk of rheumatoid arthritis: report from the study group for risk factors for rheumatoid arthritis. Ann Rheum Dis. 2012;71:638-41.

3. Bird P, Conaghan P, Ejbjerg B, McQueen F, Lassere M, Peterfy C, et al. The development of the EULAR-OMERACT rheumatoid arthritis MRI reference image atlas. Ann Rheum Dis. 2005;64:i8-10.

4. Conaghan P, Bird P, Ejbjerg PM, O'Connor P, Peterfy C, McQueen F, et al. The OMERACT rheumatoid arthritis MRI reference image atlas. Ann Rheum Dis. 2005;64:i3-7.

5. Ejbjerg B, McQueen F, Lassere M, Haavardsholm E, Conaghan $P$, O'Connor $\mathrm{P}$, et al. The EULAR-OMERACT rheumatoid arthritis MRI reference image atlas: wrist joint Ann. Ann Rheum Dis. 2005;64:i23-47.

6. Haavardsholm EA, Østergaard M, Ejberg BJ, Kvan NP, Kviein TK. Introduction of a novel magnetic resonance imaging tenosynovitis score for rheumatoid arthritis: reliability in a multireador longitudinal study. Ann Rheum Dis. 2007;66:1216-20.

7. Daniel G, Bird P, Gandjbakhch F, Haavardsholm EA, Peterfy CG, Vital EM, et al. Development and validation of the OMERACT rheumatoid arthritis magnetic resonance tenosynovitis scoring system in a multireader exercise. J Rheumatol. 2017;44:1688-93.

8. Van Steenbergen HW, van Nies JA, Huizinga TW, Bloem JL, Reijnierse $\mathrm{M}$, van der Helm-van Mil AH. Characterising arthralgia in the preclinical phase of rheumatoid arthritis using MRI. Ann Rheumatol Dis. 2015; $74: 1225-32$.

9. van Steenbergen HW, Aletaha D, Beaart-van de V, Brouwer E, Codreanu C, Combe B, et al. EULAR definition of arthralgia suspicious for progression to rheumatoid arthritis. Ann Rheum Dis. 2017;76:491-6.

10. Resnick D. Huesos y Articulaciones en Imagen. Madrid: Libros, SL; 1998. p. 15-8, 210-33.

11. Berquist TH. MRI of the Musculoskeletal System. $6^{\text {th }}$ ed. Philadelphia, PA: Lippincott Williams and Wilkins; 2012. p. 30-40, 59.

12. Colebatch AN, Edwards CJ, Østergaard M, van der Heijde D, Balint PV, D'Agostino MA, et al. EULAR recommendations for the use of imaging of the joints in the clinical management of rheumatoid arthritis. Ann Rheum Dis. 2013;72:804-14.

13. Aletaha D, Neogi T, Silman AJ, Funovits J, Felson DT, Bingham CO, et al. 2010 rheumatoid arthritis classification criteria: an American college of rheumatology/European league against rheumatism collaborative initiative. Arthritis Rheum. 2010:62:2569-81.

14. Conaghan $P$, Bird $P$, Ejbjerg $B, O$ 'Connor P, Peterfy $C$, McQueen $F$, et al. The EULAR-OMERACT rheumatoid arthritis MRI reference image atlas: the metacarpophalangeal joints. Ann Rheumatol Dis. 2005;64:111-21. 
15. Woodworth TG, Morgacheva O, Pimienta OL, Troum OM, Ranganath VK, Furst DE. Examining the validity of the rheumatoid arthritis magnetic resonance imaging score according to the OMERACT filter-a systematic literature review. Rheumatology. 2017:56:1177-88.

16. Lisbona MP, Maymó J, Carbonell J. Resonancia magnética de la mano en la artritis reumatoide. Revisión de la metodologia y la utilidade en el diagnóstico, el seguimiento y el pronóstico. Reumatol Clin 2017:3:126-36.

17. Lee KA, Min SH, Kim TH, Lee SH, Kim HR. Magnetic resonance imaging-assessed synovial and bone changes in hand and wrist joints of rheumatoid arthritis patients. Ann Rheum Dis. 2017:76:1166.

18. van Steenbergen HW, Mangus L, Reijnierse M, Huizinga TW, van der Helm-van AH. Clinical factors, anticitrullinated peptide antibodies and MRI-detected subclinical inflammation in relation to progression from clinically suspect arthralgia to arthritis. Ann Rheum Dis. 2016;75:1824-30

19. Erol AM, Ceceli E, Ramadan SU, Borman P. Effect of rheumatoid arthritis on strength, dexterity, coordination and functional status of the hand: relationship with magnetic resonance imaging findings. Acta Reumat. 2016:41:328-37.
20. Kosta PE, Voulgari PV, Drosos AA, Argyropoulou MI. The usefulness of magnetic resonance imaging of the hand and wrist in very early rheumatoid arthritis. Arthritis Res Ther. 2011;13:R84.

21. Spina JC, Dutruel $S$, Colombo O, Badano F, Aliaga L, Barreira JC. Evaluación del daño estructural de manos mediante RM en pacientes con artritis reumatoidea temprana, sin evidencia de erosiones radiográficas. Rev Arg Radiol. 2009;73:439-48.

22. Mo YQ, Yang ZH, Wang JW, Du XY, Xu YH, Yang KM, et al. Tenosynovitis on MRI of bilateral hands and its concordance with joint swelling/ tenderness in patients with early rheumatoid arthritis. Arthritis Rheumatol. 2018;70:1000-7.

23. Larios-Forte MD, García-Coronado JM, Skinner-Taylor CM, Esquivel-Valerio JA, Vega-Morales D, Vilchez-Cavazos F, et al. The very early inflammatory triquetral lesion by MRI-is this the first sign in rheumatoid arthritis? Acta Reumatol Port. 2019:44:218-24.

24. Schleich C, Buchbender C, Sewerin P, Miese F, Aissa J, Brinks R, et al. Evaluation of a simplified version of the rheumatoid arthritis magnetic resonance imaging score (RAMRIS) comprising 5 joints (RAMRIS5). Clin Exp Rheumatol. 2015;33:209-15. 